\title{
3D Multi-architectural Tissue Engineering Scaffolds: Degradation and Cell Culture Study
}

M Enamul Hoque ${ }^{1 *}$, Y Leng Chuan ${ }^{1}$, lan Pashby ${ }^{1}$, S Sheren Aini ${ }^{2}$, Angela Ng Min Hwei ${ }^{2}$ and Ruszymah Idrus ${ }^{2}$

${ }^{1}$ Department of Mechanical, Materials and Manufacturing Engineering, University of Nottingham Malaysia Campus, Malaysia

${ }^{2}$ Tissue Engineering Centre, Universiti Kebangsaan Malaysia Medical Centre, Malaysia

Tissue engineering (TE) requires a mechanically stable, biocompatible and biodegradable scaffold that allows cell adhesion, cell proliferation, cell specific properties preservation, and suitable for surgical implantations [1,2]. Therefore, fabricated TE scaffold should mimic the biomechanical properties of the organ or tissue to be regenerated. To meet such requirements, development of appropriate 3D TE scaffold remains a great challenge in terms of modelling, design and fabrication. From a design standpoint, the scaffold geometry should be produced directly from the image of the patient's defective organ, and simulate the biomechanical properties of the organ to be reconstructed. For example, the bone and cartilage tissue scaffolds usually require complex architecture, porosity, pore size, pore shape and interconnectivity in order to provide the needed structural integrity, strength, transport and ideal micro-environment for cell and tissue in growth [3]. Subsequently, the fabrication process that can build scaffolds from a range of biomaterials will be at a premium to create patient-specific scaffold. However, such materials must have the fundamental clinical approval for in vivo implantation. Rapid prototyping (RP) is an automated manufacturing process that can develop 3D scaffold by sequential delivery of energy and/or material, simulating the anatomy and properties of the tissue or organ to be regenerated [4-6]. The 3D scaffolds fabricated via various RP systems demonstrated the biocompatibility for TE applications [6,7].

The development of scaffold using slow-degrading polymers like, poly ( $\varepsilon$-caprolactone) (PCL) involves the need of long-term in vitro and in vivo studies [8]. Accelerated in vitro degradation experiment aims to achieve comparable degradation profile within a short period of time that saves time and ultimately financial resources, compared to the standard in vivo conditions. Though degradation study of biodegradable polymers is known to be widely explored, little detailed information is available regarding the effect of scaffold architecture on degradation kinetics. This current study focuses on the investigation of the in vitro degradation of PCL scaffolds with multiple architectures in $5 \mathrm{M} \mathrm{NaOH}$ solution at $37^{\circ} \mathrm{C}$. The PCL scaffolds with single- and hybriddesigns were fabricated via in-house built desktop robot based rapid prototyping (DRBRP) system [9] for the experiments. The hybriddesign integrates two or more lay-down patterns in the same scaffold unit, whereas the single-design scaffold consists of only one specific laydown pattern. The degraded PCL scaffolds were analyzed by means of differential scanning calorimeter (DSC), thermo gravimetric analyzer (TGA), scanning electron microscope (SEM), and densimeter. The degradation study demonstrated that both single- and hybrid-design PCL scaffolds realized homogeneous hydrolytic degradation via surface erosion resulting in a consistent and predictable mass loss. However, the architectural variation (i.e. single- or hybrid-design) did not influence the degradation kinetics. In vitro cell culture study was also conducted on single- and hybrid-design PCL scaffolds using osteoprogenitor cells. SEM and confocal laser microscopy (CLM) showed significant cell attachment, proliferation, and extracellular matrix formation on the surface as well as inside the structure of both types (single- and hybrid-design) of scaffolds. However, the hybrid-design scaffolds exhibited better performance in cell culture study than the single- design scaffolds. Overall, the characterization results suggest that the hybrid-design scaffolds offer better optimized properties that could be of great value for regenerative therapies.

\section{References}

1. Joseph JG (2006) Polymers for tissue engineering, medical devices, and regenerative medicine. Concise general review of recent studies. Polym Adv Technol 17: 395-418

2. Moroni L, Schotel R, Sohier J, de Wijn JR, van Blitterswijk CA (2006) Polymer hollow fiber three-dimensional matrices with controllable cavity and shell thickness. Biomaterials 27: 5918-5926.

3. Lacroix D, Chateau A, Ginebra MP, Planell JA (2006) Micro-finite element models of bone tissue-engineering scaffolds. Biomaterials 27: 5326-5334.

4. Tan JY, Chua CK, Leong KF (2010) Indirect fabrication of gelatin scaffolds using rapid prototyping technology. Virtual Phys Prototyp 5: 45-53.

5. Hoque ME, Chuan YL, Pashby I (2012) Extrusion based rapid prototyping technique - An advanced platform for tissue engineering scaffold fabrication. Biopolymers 97: 83-93

6. Ovsianikov A, Malinauskas M, Schlie S, Chichkov B, Gittard S, et al. (2011) Three-dimensional laser micro- and nano-structuring of acrylated poly(ethylene glycol) materials and evaluation of their cytoxicity for tissue engineering applications. Acta Biomaterialia 7: 967-974.

7. Lee JW, Kang KS, Lee SH, Kim JY, Lee BK, et al. (2011) Bone regeneration using a microstereolithography-produced customized poly(propylene fumarate) diethyl fumarate photopolymer 3D scaffold incorporating BMP-2 loaded PLGA microspheres. Biomaterials 32: 744-752.

8. Chen Y, Zhou S, Li Q (2011) Microstructure design of biodegradable scaffold and its effect on tissue regeneration. Biomaterials 32: 5003-5014.

9. Hoque ME Chuan YL (2011) Desktop Robot Based Rapid Prototyping (DRBRP) System: An Advanced Extrusion Based Processing of Biopolymers into 3D Tissue Engineering Scaffolds. In: M. Enamul Hoque, Rapid Prototyping Technology - Principles and Functional Requirements. Croatia: InTech Open Access Publisher.

*Corresponding author: M Enamul Hoque, Department of Mechanical, Materials and Manufacturing Engineering, University of Nottingham Malaysia Campus, Malaysia, E-mail: enamul.hoque@nottingham.edu.my

Received August 03, 2012; Accepted August 06, 2012; Published August 08 2012

Citation: Hoque ME, Chuan YL, Pashby I, Aini SS, Hwei ANM, et al. (2012) 3D Multi-architectural Tissue Engineering Scaffolds: Degradation and Cell Culture

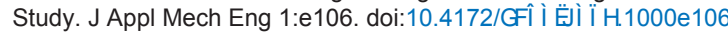

Copyright: (c) 2012 Hoque ME, et al. This is an open-access article distributed under the terms of the Creative Commons Attribution License, which permits unrestricted use, distribution, and reproduction in any medium, provided the original author and source are credited. 